\title{
Teaching spoken discourse markers explicitly: A comparison of III and PPP
}

\author{
CHRISTIAN JONES* \& RONALD CARTER** \\ * University of Central Lancashire \\ ** University of Nottingham
}

Received: 18/10/2012. Accepted: 21/02/2013.

\begin{abstract}
This article reports on mixed methods classroom research carried out at a British university. The study investigates the effectiveness of two different explicit teaching frameworks, Illustration - Interaction Induction (III) and Present - Practice - Produce (PPP) used to teach the same spoken discourse markers (DMs) to two different groups of Chinese learners and compared to a control group. Univariate analysis of the pre- and post-tests indicated statistically significant differences between the PPP group and III/control groups in terms of a higher mean usage of the target DMs in the immediate post-test. Qualitative results demonstrated that the PPP group generally found this method to be more useful, which tallied with their better performances in the tests. Both groups also articulated a desire for a different kind of practice to be used in class, based on rehearsal for real world tasks. This suggests a need to re-conceptualise practice within III, PPP or other teaching frameworks.
\end{abstract}

KEYWORDS: Discourse markers, spoken grammar, explicit teaching approaches, PPP, III.

\section{RESUMEN}

Este artículo presenta resultados obtenidos a través de una investigación en el aula en una universidad británica. El objetivo del estudio es la comparación de la efectividad de dos modelos explícitos de enseñanza diferentes: Ilustración - Interacción - Inducción (III) y Presentación - Práctica - Producción (PPP), empleados para enseñar marcadores del discurso a dos grupos distintos de estudiantes chinos y comparados con un grupo de control. Los resultados de un análisis univariado de las puntuaciones en el pre-test y el post-test indican diferencias estadísticamente significativas entre el grupo PPP y el grupo III (el grupo de control) relativas a un mayor uso de los marcadores del discurso durante el post-test inmediato. Los resultados cualitativos demuestran que, en general, los participantes del grupo PPP consideran este método más útil. Dichas opiniones coinciden con el mejor rendimiento en los tests. Otra conclusión relevante es que los dos grupos expresaron su deseo de que se aplicase otro tipo de práctica en la clase, como, por ejemplo, actividades que sirviesen de entrenamiento para tareas fuera de la clase, en el mundo real. Esto sugiere la necesidad de reformular el concepto de práctica en III, PPP y otros modelos de enseñanza.

PALABRAS CLAVE: Marcadores del discurso, gramática hablada, enfoques explícitos en la enseñanza, PPP, III.

\footnotetext{
*Address for correspondence: Christian Jones. School of Language, Literature and International Studies, University of Central Lancashire, Preston, PR12HE, UK; e-mail cjones3@uclan.ac.uk.
} 


\section{INTRODUCTION}

In a recent review of research into spoken language, Timmis (2012) highlights some findings, areas of debate and potential ways forward for future research. He describes how recent research in corpus linguistics has done much to provide a clearer picture of how spoken grammar and written grammar differ in at least some respects. Some key findings of Biber Johansson, Leech and Finegan (1999), Carter and McCarthy (1997, 2006) McCarthy and Carter (1995) and Leech (2000), for instance, show that spoken grammar contains features such as ellipsis, tails and discourse markers with greater frequency than we might intuitively guess.

At the same time, there has been considerable debate about whether teachers need to teach these forms to students wishing to be successful users of English or 'SUEs' (Prodromou, 2003, 2008), particularly those using English in lingua franca contexts. Timmis (2012) suggests that the debate revolves around the link between native speaker usage and cultural identity. A spoken corpus based upon native speaker data may tell us the most frequent forms in use but some of these may be linked directly to a particular cultural identity and therefore may not be the most useful items for learners.

However, as Timmis (2012) also acknowledges, there have been few empirical studies which have investigated the teaching and learning of spoken grammar in classroom contexts. This suggests that research which investigates how to best teach forms which could help learners to become SUEs is worthwhile, providing the forms chosen are appropriate for the context in which learning takes place. DMs are not highly idiomatic and do not seem to be a mark of cultural identity in the way that slang or colloquial language can be and are therefore likely to be worth acquiring for productive use in ESL classrooms. Data from spoken corpora indicate that DMs are very common in (at least) native speaker speech. 'You know' and 'I mean', for example, are the first and second most frequent two-word chunks in the CANCODE spoken corpus of British English (O'Keeffe, McCarthy \& Carter, 2007:65). The frequency of DMs is as a result of them having a number of useful functions in speech such as showing listenership or opening conversation but their high frequency may also mean that they do not always stand out and can seem banal or irrelevant to learners (Jones, 2010). Despite this, they rarely appear in textbooks (Cullen \& Kuo, 2007) and have only occasionally been the subject of classroom research. This study is therefore a small attempt to address the gap in empirical research which Timmis (2012) highlights by attempting to answer the following research questions:

RQ1. To what extent does explicit teaching aid the acquisition of spoken discourse markers by intermediate (CEFR B2) level Chinese EAP learners studying in the UK? 
RQ2. Which explicit framework aids acquisition of the target DMs more - a PPP framework which practices the target DMs or an III framework which helps students to notice the target DMs but does not practise them in class?

RQ3. To what extent do the learners themselves believe one classroom approach to learning DMs (PPP/III) is more helpful than the other?

\section{LITERATURE REVIEW}

\subsection{What are discourse markers?}

Schiffrin (1987: 31) offers an early definition when she suggests that DMs are "sequentially dependent elements which bracket units of talk" and which help to make discourse coherent. She suggests that a DM connects directly to the "unit of talk" prior to it and following it. These units help to determine the choice of DM and the meaning speakers intend and listeners infer. Her analysis, based on native speaker corpus data, suggests that one function of DMs is to coordinate talk, which is defined on five different "planes": information state, participation framework, ideational structure, action structure and exchange structure (Schiffrin, 1987:35-40). Redeker offers a definition of a DM (in her terms a "discourse operator") which differs slightly from Shiffrin: "A discourse operator is a word or phrase for instance, a conjunction, adverbial, comment clause, interjection - that is uttered with the primary function of bringing the listener's attention to a particular kind of linkage of the upcoming utterance with the immediate discourse context. An utterance in this definition is an "intonationally and structurally bounded, usually clausal unit" (Redeker, 1991: 1168).

Fraser (1996, 1999) further develops the work of both Redeker (1991) and Schiffrin, (1987) with some difference in emphasis. He suggests that DMs have a procedural meaning and relate the "discourse segment" they are part of to a previous segment. This means that Fraser differs in terms of what he accepts as being a DM. He suggests, for instance, that adverbials such as 'frankly' are not DMs because they are "commentary markers" and "do not signal a two place relationship between the adjacent discourse segments" (Fraser, 1999: 942). He also suggests that "pause markers" such as 'well' and 'um' and interjections such as 'wow!' are not DMs for the same reason. More recently, Aijmer (2002) has produced a corpus-based analysis of a number of DMs (defined here as "discourse particles"). Her work finds common ground with some of the previously discussed research. She agrees with Fraser (1999), for instance, in suggesting that DMs do not have propositional meanings (Aijmer, 2002: 16). She also accepts that we cannot limit DMs to one part of speech. In addition, Aijmer proposes that DMs can be analysed on two "macro levels" (Aijmer, 2002: 13): "textual" and "interpersonal". This definition has been developed further by Fung and Carter (2007), who have analysed data from a spoken corpus to suggest four macro levels: structural, referential, interpersonal and cognitive, each subdivided to show what we might 
term 'micro functions'. Table 1, an excerpt from Fung and Carter (2007: 418), provides an illustration of their analysis.

$\begin{array}{llll}\begin{array}{l}\text { Interpersonal } \\ \text { Marking shared } \\ \text { knowledge: }\end{array} & \text { Referential } & \begin{array}{l}\text { Structural } \\ \text { Opening and closing of } \\ \text { topics: }\end{array} & \begin{array}{l}\text { Cognitive } \\ \text { Denoting thinking } \\ \text { process: }\end{array} \\ \begin{array}{l}\text { know, listen } \\ \text { But, and, yet, however, }\end{array} & \begin{array}{l}\text { Now, OK/okay, } \\ \text { right/alright, well, } \\ \text { let's start, let's discuss, } \\ \text { let me conclude the } \\ \text { discussion }\end{array} & \text { Well, I think, I see }\end{array}$

Table 1. Macro levels and micro functions of DMs

This functional definition is a useful model of analysis because it highlights both the textual and interpersonal uses of DMs. It acknowledges that DMs aid coherence in speech but also serve (sometimes simultaneously), interpersonal functions such as showing interest. It is this functional definition that is employed in this article. To summarise, we can define a DM in the following ways:

1. DMs are lexical items or phrases (Carter \& McCarthy 2006; Redeker, 1991), such as 'right', 'I mean', 'you know' and 'I think'.

2. DMs are optional - the absence of a DM does not affect the semantics or grammar of an utterance. However, the absence will make comprehension at least more difficult (Aijmer, 2002; Eslami \& Eslami-Rasekh, 2007).

3. DMs are often multifunctional. Fung and Carter (2007) give the example of 'so', which can, for instance, both summarise and launch a topic.

4. DMs are not drawn from one grammatical class and are not a closed grammatical class. Aijmer (2002), Carter and McCarthy (2006) and Fung and Carter (2007), give examples of DMs such as prepositional phrases ('by the way'), response tokens ('right') and interjections ('oh').

5. DMs have a procedural but not propositional meaning. A DM may possess a propositional meaning when used as part of another class. An example of this is the temporal use of 'now'. The meaning of a DM can be defined from the broader context in which it operates.

6. DMs function at a referential, interpersonal, structural and cognitive level (Aijmer, 2002; Fung \& Carter, 2007). They act as signposts for speakers and listeners as they orientate themselves to the ongoing discourse (Aijmer, 2002; Schiffrin, 1987). 


\subsection{Previous research}

Various aspects of spoken grammar and lexico-grammar have been the focus of research, including vague language (e.g., Channell, 1994), and DMs (e.g., Aijmer, 2002; Fraser, 1996; Fraser, 1999; Fung \&Carter, 2007; Hellermann \&Vergun, 2007; Jucker \& Ziv, 1998; Muller, 2004; Schiffrin, 1987). Studies have also been conducted in English for Academic Purposes (EAP) contexts (e.g., Chaudron \& Richards, 1986; Clenell, 1999; Cutting, 2000; Eslami $\&$ Eslami-Rasekh, 2007). However, much of this research has focussed upon analysing the language itself or comparing native and non-native usage and there have been few empirical studies which have sought to test specific methodologies in relation to the teaching of spoken grammar. Timmis (2005), has tested a teaching framework which encourages students to notice aspects of spoken grammar within authentic listening texts. He produced a series of lesson materials which helped students to globally understand listening input, before employing tasks which sensitised them to the spoken grammatical forms employed by speakers. Students were not asked to produce any of the spoken grammatical forms. Timmis solicited the views about the materials and class content from both learners and teachers via a sample of questionnaires. Results show that the majority of teachers and learners felt this approach was useful and it is unfortunate that few other studies have been conducted along similar lines.

There are also a small number of studies which have used classroom research to investigate the teaching and learning of DMs, Yoshimi (2001) produced evidence that presentation and explicit explanation of DMs, followed by practice and corrective feedback, helped learners to use them within informal spoken narratives to a much greater extent than a control group given no explicit focus on the same items. Yoshimi's study focussed on explicit instruction of three Japanese discourse markers 'n desu', 'n desu kedo 'and 'n desu ne' used in the context of narrating spoken anecdotes (Yoshimi, 2001:244). Each group was given a pre-and post-test in which learners were asked to complete a story telling task (Yoshimi, 2001:224). Quantitative analysis revealed large gains in use of the target DMs for the experimental group and no gains for the control group. This suggests that explicit instruction, communicative practice and corrective feedback did help to improve use of the target items.

Hernandez (2008) tested the differences between explicit instruction of Spanish DMs combined with input flood (an artificially large number of DMs used in input), compared to input flood alone. The findings show that explicit instruction and input flood had a greater impact on an experimental group when compared to the group who received input flood alone. Although a similar study (Hernandez, 2011) did not replicate the results entirely, it did show that explicit instruction and input flood increased the number of target DMs used in post-tests more than input flood alone. 


\subsection{Research gaps}

It is clear that there has been only a small amount of classroom research which has sought to investigate the most productive ways to teach aspects of spoken grammar, including DMs. PPP is well-established in mainstream ELT methodology (e.g., Lindsay \& Knight, 2006) but has attracted a lot of criticism (e.g., Skehan, 1996). Whilst some of the criticism of PPP seems well-founded, it is also the case that practice within ELT methodology has been underresearched, something very surprising considering it is so well-established as part of Communicative Language Teaching (CLT) methodology (DeKeyser, 2007a: 1). It is often taken for granted that part of the job of a teacher is to follow a PPP framework and to present learners with language, to check form, meaning and use and then provide some practice, in the belief that this will help them to internalise the forms and become able to use them productively. Although generally unstated in descriptions of methodology, this belief seems to be founded on the idea that learning a language is akin to developing a skill and the three common phases of PPP have been related to Anderson's (1982) skill building model:

1. A cognitive phase, when a learner makes a conscious effort to learn the meaning and form of language (Present).

2. An associative phase, when a learner will try to transfer declarative knowledge into procedural knowledge (Practice).

3. An autonomous phase, when a learner will be able to use the language spontaneously (Produce).

This has a certain ring of common sense to it but, as Ellis (2002) notes, it is also something of an unchallenged orthodoxy in CLT. There is some research evidence to suggest that it does help learners to freely produce language they have practised (e.g., DeKeyser, 2007a) but also evidence that it does not help (e.g., Ellis, 2002). This suggests that the orthodox view, that practising language in class does help learners to acquire it, is at least worthy of investigation. Perhaps it is possible that "noticing" (Schmidt, 1990) features of spoken grammar alone may help learners to eventually acquire them for their own productive use and that a case can be made for the use of an III framework (McCarthy \& Carter, 1995) based on a different three phase model of acquisition, which Ellis (2002:171) suggests:

1. A noticing phase, when a learner "becomes conscious of a feature in the input, whereas previously she had ignored it" (Illustration).

2. A comparing phase, when a learner "compares the linguistic feature in the input with her own interlanguage, registering to what extent there is a 'gap' between the input and her interlanguage" (Interaction). 
3. An integrating phase, when a learner "integrates a representation of the feature into her mental grammar" (Induction).

If this model does work, it suggests that output practice in the English language class may not always be a productive or necessary use of classroom time, particularly when learners are in an EAP context and constantly hearing/using spoken English in their daily lives. Classroom time is always limited and it is worth asking whether that time is more productively spent, in this situation, giving learners practice or simply helping them to notice features of language.

\section{METHODOLOGY}

\subsection{Participants}

Thirty six Chinese learners (fourteen male, twenty two female) were assigned to three groups, experimental group 1 (III), experimental group 2 (PPP) and group 3 (control). Although this is a relatively small sample size, it is comparable to similar experimental studies employing classroom research, such as Van Patten and Cadierno (1993). This means that the study can give indications about the population as a whole, which will need to be developed in further studies with larger samples. All students were given the same standardised placement test at the start of their three week EAP pre-sessional course and only learners who had tested at CEFR B2 level were chosen to take part in the study. A learner's competency at this level can be broadly defined as someone who "Can interact with a degree of fluency and spontaneity that makes regular interaction with native speakers quite possible without strain for either party" (Council of Europe, 2001: 24). The initial study was conducted over five days, with a two hour lesson offered each day. Students had been in the UK, on average, for three weeks prior to the start of the study.

\subsection{Study design}

This study employed elements of an experimental design often used in this type of research (Cohen, Mannion \& Morrison, 2007:275) because it compared three groups of twelve learners at the same proficiency level, and used a pre-, post- and delayed test as one form of data collection. The design was intended to measure which teaching framework was more effective in terms of acquiring the target DMs and the use of a control group aimed to demonstrate that the target items would not be acquired through simple exposure to input in the English speaking environment i.e. that there was a positive effect for explicit teaching.

In addition, two further measures were employed in the use of learner diaries and focus groups. The solicited diaries were intended to gain participant data from each experimental 
group: how they responded to what they were learning (the target DMs) and how they were learning them (through a PPP or an III framework) over the course of the study. Learners were asked to write about what they had learnt and how they had learnt in class. Ensuring learners remain motivated to complete diaries is often an issue with diary studies (Krishnan \& Hoon, 2002: 227). In order to maintain motivation, learners were provided with a model and briefing session at the start of the course, diaries were collected at regular intervals and a corrected version of each entry was handed back to learners. Only the original data was used for the study but spellings were corrected to facilitate analysis.

Focus groups were held immediately after the study and used a series of broad prompts to initiate discussion. Six students were chosen for each group and both featured an equal mix of male and female students. The choice of focus groups themselves rather than individual interviews was partly a practical one; as recording and transcribing twenty four individual interviews would have taken considerably more time than was available. It was also hoped that the discussion which would take place in the focus groups would allow for a richness of data which individual interviews may not always develop (Morgan, 1997).

The tests took place immediately prior to classes, immediately after classes and then after a delay of eight weeks. They employed a free constructed response format, using a paired, interactive speaking test, from a commercially available exam. Students were given the opportunity to use the DMs in focus but were not explicitly pushed to do so. The test chosen has been extensively piloted both in its design and choice of topics to ensure a good variety of interaction between the interlocutor and students and between students themselves. In order to militate against any practice effect, question topics were changed at each test stage. In addition, by examining recordings of the test made with learners at the same level who had not been subject to any experimental instruction, we could see these learners made use of several of the target DMs, suggesting there was ample opportunity to use them. There was a danger in using a free constructed response test that learners would simply avoid using the target DMs but as we wished to measure acquisition it was felt that this was the best test type to employ, as a more controlled test would not have measured the ability of learners to use the target DMs productively.

Overall, a mixed methods design was chosen because learners' subjective impressions of different methodologies have tended to be neglected in classroom research of this kind (e.g., VanPatten \& Cadierno, 1993) and findings have been based largely on test scores alone. Given that the acquisition of language in an instructed context is likely to be at least affected by how a learner responds to a certain type of teaching, this seems a serious omission.

\subsection{Data analysis}

Recordings of tests were made and a researcher and colleague watched and counted the target DMs used correctly, with the right function and broadly correct pronunciation. These scores 
were then measured using one-way ANOVA and post-hoc S-N-K tests with SPSS software to check for statistical significance in terms of overall scores in these areas (pre-, post- and delayed tests) and in terms of gains made between each stage (as suggested by Dornyei, 2007: 219-221).In addition to the statistical analysis, the raw scores were analysed as it was felt they were also illustrative.

The diary and focus group data were analysed in three main ways. First, the data was coded into categories, using NVIVO 8 software (QSR International, 2012). Second, corpus software (Lextutor, 2012) was used to produce lists of the most frequent words in the data. Third, concordance lines of several frequent words were generated to illustrate how the words were being used in the data by the different groups of learners. Computer assisted qualitative data analysis (CAQDAS) software allowed us to approach coding in a way which was more systematic and thus more objective than manual coding (Kelle, 2002: 486). This meant we could review our codes many more times than if we had done this manually and thus we could attempt to ensure that our view of the data was not a partial or biased interpretation.

\subsection{Pedagogy}

The target DMs chosen can be found in the Appendix. The defining differences between the III and PPP frameworks was that the III group were not given any practice of the target DMs (either pre-communicative or contextualised) but were given a number of tasks which encouraged them to notice aspects of the DMs such as discussing the difference between the DMs in English and their L1. The PPP group were given pre-communicative and contextualised practice of the DMs in activities such as drills, making dialogues and roleplays which encouraged use of the target items.

\section{RESULTS}

\subsection{RQ1: To what extent does explicit teaching aid the acquisition of spoken discourse markers by intermediate (CEFR B2) level Chinese EAP learners studying in the UK?}

Table 2 below shows the number of DMs used by each group at each test stage.

\begin{tabular}{|lrrr|}
\hline & Pre-test & Immediate post-test & Delayed post-test \\
\hline III group & 3 & 15 & 11 \\
\hline PPP group & 19 & 39 & 34 \\
\hline Control group & 10 & 3 & 11 \\
\hline
\end{tabular}

Table 2. Number of target discourse markers used: Pre-, post- and delayed test 
The scores in this table show that the experimental teaching, as we would expect, had an impact on both groups and that being in an English speaking environment, as the control group were, did not in itself greatly increase use of the target DMs. In terms of the raw scores only, the impact was clearly greater on the PPP group, particularly at the immediate post-test stage. Although the control group also increased their usage over time, the increase was by only one DM from pre- to delayed test, compared to an increase of eight DMs in the III group and fifteen in the PPP group. In addition, the control group's usage of DMs decreased in the post-test, indicating that input from the English-speaking environment alone did not produce consistent results in terms of how the target language was acquired.

We can demonstrate the positive impact instruction had with a sample from one immediate post-test by the III group:

Part 1 (Teacher-Students)

$<$ S 10>: I think my family is a helpful family, if err, if my family have something, like err, something, we will discuss together and err, they can show themselves ideas or something like that.

Part 2 (Student-Student)

$<$ S 12>: To be honest, I don't agree that shopping online is not safe

$<$ S 01>: Why?

$<\mathrm{S} 12>$ : Be=you see, sometime, sometimes the product in the internet, I saw it but I can't touch it.

$<$ S 06>: But the fee about email, fee about email, who pay?

$<$ S 03>: Pay?

$<$ S 06>: Fee about I send...Like facebox, like EMS.

Part 3 (Teacher-Students, Student-Student)

$<$ S 01>: If the problem is not serious, we will not complain because, you know, it's waste time

\subsection{RQ2: Which explicit framework aids acquisition of the target DMs more - a PPP framework which practices the target DMs or an III framework which helps students to notice the target DMs but does not practise them in class?}

Significance was assumed if probability (p) was shown to be .05 or less $(\mathrm{p} .<.05)$. Mean gain scores in DM usage and mean totals of DMs usage were analysed. Gain scores in DM usage at pre-post, post-delayed and pre-delayed stages did not reveal significant differences between the groups. A one way ANOVA revealed that there was a significant difference in the total amount of target DMs used in the immediate post-test by the PPP group $(\mathrm{m}=$ $3.4167, \mathrm{SD}=3.449686)$ when compared to the III $(\mathrm{m}=1.2500, \mathrm{SD}=1.13818)$ and control groups $(\mathrm{m}=0.2500, \mathrm{SD}=.62158)$. The mean total of the target $\mathrm{DMs}$ used was significant ( $\mathrm{p}$. $=.003$ ) at this stage only. Tables 3 and 4 show the results from the one way ANOVA and post-hoc S-N-K test. 


\begin{tabular}{|lcrrrr|}
\hline & $\begin{array}{c}\text { Sum of } \\
\text { Squares }\end{array}$ & Df & $\begin{array}{c}\text { Mean } \\
\text { Square }\end{array}$ & F & Sig. \\
\hline Between Groups & 62.889 & 2 & 31.444 & 6.945 & .003 \\
\hline Within Groups & 149.417 & 33 & 4.528 & & \\
\hline Total & 212.306 & 35 & & & \\
\hline
\end{tabular}

Table 3. One way ANOVA comparing total amount of target DMs used at the immediate post-test stage

\begin{tabular}{|lccc|}
\hline Group & $\mathrm{N}$ & \multicolumn{2}{c|}{ Subset for alpha $=0.05$} \\
\hline & \multicolumn{2}{c|}{2} \\
\hline 3(Control) & 12 & .2500 & \\
1 (III) & 12 & 1.2500 & 3.4167 \\
2(PPP) & 12 & & 1.000 \\
Sig. & & .258 & \\
\hline
\end{tabular}

Table 4. Student-Newman-Keuls post-hoc test (means for groups in homogeneous subsets are displayed)

This result supports the result shown in Table 2 and suggests that in the short term only, the PPP framework led to a greater increase in usage of the target DMs and the treatment had more impact upon this group, based on this measure only.

\subsection{RQ3. To what extent do B2 level Chinese EAP learners themselves believe one classroom approach to learning DMs (PPP/III) is more helpful than the other?}

Each diary entry was typed and then analysed using NVIVO 8 software (QSR International, 2012) to formulate categories. The categories comprised 'methods', 'class description', 'noticing', 'practice' and 'usefulness' as it was felt that each could contribute to answering research question three. The entries chosen as examples here were considered to be prototypical comments made by the whole group, as it was not possible to display and discuss each diary entry.

Several salient points emerge from this data. Firstly, the diaries indicate that both groups found the language useful and felt it was worth studying. Examples of comments which indicate this are as follows:

(III) In my opinion, the discourse markers are useful than only speak English because I had to think and use the expressions with correct meaning. Finally, its benefit to my grammar and teaching me how to choose these words in colloquial sentence.

(PPP) Before this class, when we say that sentences we always say the full sentences, after this class we know a lot of short sentences to say the something. That's helpful and useful in our daily life, that's sentences will more clear to UK local life. 
There were some differences in the way each approach was viewed. Learners from the III group did feel that language awareness tasks which encourage noticing were of use to them. For example:

(III) Then we also learner some short dialogs from teacher, we understand the difference between these English dialogs and Chinese dialogs. I think it will help us make less mistake possible when we talking with others.

Similarly, the PPP group were generally positive about the methodology used and in particular about the use of practice. Comments such as the following illustrate this:

(PPP) Finally, we used these language to practise the conversation again with our partner about the best or worst holiday you have ever had. This kind of practice can help me improve my spoken language.

(PPP) And finally we told our own stories by using what we learned to each other to practice. This is a good way that practice directly after learned we can remember that easily.

There were, however, a few reservations expressed about the benefits of practising in class by the PPP group, such as the following:

(PPP) Maybe in the future, XXX could add more situational conversation practice into the class, looking forward to the next class.

(PPP) However, when XXX let us to do the practise I found that I still couldn't express fluently I had few vocabularies. It's my biggest weak point.

Despite these reservations, overall there were more positive comments from the PPP group about methodology and about the use of practice in particular.

These findings are supported when we look at the common words used in the diaries. The high frequency of the word 'useful' by the PPP group (ranked at twenty one) and the fact that this word does not appear in the III group's list supports the suggestion that the PPP group made more positive comments about the type of instruction they received. Similarly, the PPP group's use of the word 'practice' (ranked at fifty) also seems to support the idea that this group mentioned it more, often positively The word 'practice' does not appear in the III group's top fifty words. Concordance lines from the PPP group's data offer support for this:

1. In a words, the practices are USEFUL for me to memorise what I have learned.

2. Today I have learnt some phrases. I think they are USEFUL I can use them in conversation.

3. The language I learned today is very USEFUL in my daily life. 
1. This is a good way that PRACTICE directly after learned we can remember that

2. We did a game with our deskmates. Due to enough PRACTICE of this game, I can understand it well and use it.

3. We did PRACTICE with our classmates. I think that's enjoyable and useful enjoyable.

When the III group used similar words, they tended to refer to listening practice and use the words 'interesting' and 'useful' about the classes as a whole and not activities which are specifically linked to the type of instruction they received. Several students from the III group also expressed a desire for more practice.

The focus group data, which was analysed in the same way as the diary data, in general supported the results described so far, with some noteworthy differences. Only the focus group comments are used here. First, learners from the III group were, on the whole, less positive about the teaching methods used and the III group's comments also revealed some more specific aspects of the instruction they did not find useful. One student, for example, mentioned a dislike of 'back translation' exercises (students translate from English to Chinese and then from Chinese back into English. They then compare with the original English text):

(III) $<$ S 04>: I agree with this point and I also have suggestion, maybe, the most of the time you do one exercise and do it again and do it again and translate to English and translate to Chinese, it's very boring, I don't want to do that $(<\mathrm{S} 00>$ : Right) because we do it again some words we remember that and do again and most of words I remember that and translate to English err, I can $(<\mathrm{S} 03>$ : Just a job, it's not very easy to remember it).

The III group also felt more practice would be useful to them and made several comments to this effect, such as the following:

(III) $<$ S 06>: I think maybe this method may be [says in Chinese] $(<\mathrm{S} 02,<\mathrm{S} 04>$ : Suitable) suit for Chinese people because we like this method ( $<\mathrm{S} 00>$ : Uh huh).

$<$ S 06 $>$ : Err, when we, when we are, when we were at err, in junior, junior school, high school, ( $<$ S 00>: Uh huh) we always, teacher always tell us how to do this err, make, err, do this, do this advertise [inaudible] and so on. We always practise it.

The $<$ S $05>$ : Yes.

(III) $<$ S 01 $>$ : Err, I think, some more practice must be fair [Laughter] $(<\mathrm{S} 00>$ : [Laughs] $\mathrm{OK}$, yeah) because I always forget some discourse marks ( $<$ S $00>$ : Sure) and err, I don't know how to put in my mind and if I practise it can be more useful in the daily life.

The PPP group also agreed that practice was useful:

(PPP) $<$ S 04>: I think sometimes, the conversation is very useful, $(<\mathrm{S} 00>$ : $\mathrm{Hmm})$ because it can teach us how to, teach us make the discourse marking in the right, in the correct location, yeah.

(PPP) $<$ S 03 $>$ : I, I, I think practice is for, suitable for most of our Chinese student, but just $(<$ S 04>: Yeah) 
However, students from both groups commented on the need for some practice to take place outside the classroom and be more directly related to real life. For example:

(PPP) $<$ S 03>: I think you can actually take us to some places, for example, take us to the supermarket and you act what we learn, yeah that, that's more vivid.

(PPP) $<$ S 03 $>$ : Erm, I think the class should include more, more practice like the $(<\mathrm{S}$ 04>: Action?) practice in the field, is just acted, just not, not just the learning in the class but actually use it in your daily life $(<\mathrm{S} 00>$ : OK) and, it could, erm, I think you can check whether you, whether we used it in our daily life.

(III) $<$ S 03 $>$ : Yes, but I, I thin $=$ I have err, a comment is we can go out, outside the class to learn something, yeah, just like go to the mall to learn how to $(<\mathrm{S} 01>,<\mathrm{S} 02>$ : Shopping, $<$ S 04>: Yeah) $(<$ S 00 $>$ : OK), it's close to the life $<$ S 06: chatting $>)$

Both groups also made the suggestion that each method would have worked better in multilingual groups and there were a number of doubts expressed by the PPP group about how useful practice is in a monolingual class:

(PPP) $<$ S 05>: If only one nationality in the class it's useless. $<$ S 00>: To practise? $<$ S 05>: Yes.

(PPP) $<$ S 02>: Practice, err, I say sometimes maybe help but sometimes for example you gave me the discourse markers and we practised with $<$ S $01>(<\mathrm{S} 00>$ : Yeah $)$ we finished very fast $(<\mathrm{S} 00>$ : Yes), 'Well, the sentence', 'Do you know the sentence?' $(<\mathrm{S}$ $00>$ : OK) very fast because we are familiar and we know what to say. $(<\mathrm{S} 00>$ : Ah, OK. I mean, I, we really know the meaning and we think it's easy $(<\mathrm{S} 00>$ : OK, OK) to go.

From both sets of qualitative data, we can see that both groups felt the language was useful and linked to daily life. In the focus groups, both groups suggested that the language would help them with everyday interaction in English and they felt sure that lessons did help them to learn the target DMs, as opposed to just acquiring them from the input available to them in the UK. Practice was mainly seen as helpful and familiar, reinforcing the better test results gained by the PPP group. There were, however, some reservations about the benefits of practising in monolingual groups. In the focus groups, while both sets of learners often made positive comments about practice, they also expressed a desire for it to be more closely linked to real-world tasks, taking place outside the classroom.

\section{CONCLUSIONS}

As we would expect, both frameworks had an impact on output of the target DMs, in that they increased the usage to a greater extent than no teaching at all. This substantiates the claims made for explicit teaching methodologies (Norris \& Ortega, 2000, 2001), namely that they do have some impact on the language students acquire, which they may not always 'pick up' from the English-speaking environment. In this study, the use of a PPP framework can be 
considered more effective because it resulted in a greater ability of students to use the DMs in the short term but this was not sustained over time. Test results show a decrease in the number of target DMs used from immediate to delayed post-test and there were no statistically significant differences between the groups' usage of target DMs at the delayed test stage. Although this may in part be due to the relatively small sample size, it also suggests that there is attrition over time and therefore there is a need to regularly revisit target items in class, over an extended time period.

Critics who dismiss PPP are both right and wrong. Clearly, it did have at least a shortterm impact upon learners' ability to use the target items in this study and many of these learners felt that it was a useful framework because it offered them opportunities to practise them. It would therefore be premature to claim that it is a discredited framework, as some have suggested (e.g., Lewis, 1993; Skehan, 1996). However, it is also clear that practice within a PPP framework was not always considered as helpful by students in this context. For example, it was seen as inauthentic when students were asked to have conversations that they had already had in their L1. Here it was not viewed as skill building but time wasting. Therefore, we can conclude that there is a need to re-conceptualise and investigate what we mean by language practice in the classroom, in PPP and other teaching frameworks.

DeKeyser (2007b: 295) suggests that "good practice consists of activities that make students process form-meaning links". Ortega (2007: 182-184) argues that practice should have meaning, allow for interaction and have a focus on the forms needed to complete the task. One would assume that learners in the context we have studied would be in a perfect position to get just these kinds of practice. They are in an English speaking country, they need to use English (at least) in the university environment and they will certainly hear and need to respond to a great deal of English in written and spoken form. The problem is that the study abroad experience can often lead to learners feeling overwhelmed. This can produce feelings of failure and the desire to withdraw from situations which might help them to practise (DeKeyser, 2007c: 218-219). There was certainly evidence of this in both focus groups, where learners expressed a desire to learn within classes of multilingual learners and for tasks to be based on real-world interaction. DeKeyser (2007c) lists a number of ways we might help learners in this situation, including work on language functions, strategies and listening before they arrive. Once they are in the English speaking environment (in this case, the EAP environment in the UK) he suggests that "the most crucial intervention is to give them assignments that force them to interact meaningfully with native speakers and overcome their fear of speaking" (DeKeyser, 2007c: 218). While we would not agree that interaction must take place only with native speakers, the data certainly suggests that a teaching framework could be adopted which featured tasks, noticing and consolidation, in various combinations. Tasks could consist of real-world activities in the broad EAP environment and wider community, which would involve interaction with both native and non-native speakers to fulfil transactional and interpersonal goals. Noticing in this framework would particularly 
focus on listening in the early stages and making learners explicitly aware of spoken DMs which may facilitate interaction and discourse management. Consolidation might involve learners feeding back on tasks they have completed and asking for help, or precommunicative practice such as repetition of common DMs and memorising short sample conversations featuring the target forms.

Further research in this EAP context could usefully investigate the teaching of DMs or other aspects of spoken grammar by comparing other explicit frameworks in order to find out which might be the most effective. We might use the type of noticing, task and consolidation framework we have suggested and compare it with III or PPP, using larger sample sizes where possible. Another option would be to provide the explicit instruction over a longer period of time and use the same methods of data collection. If possible, for example, it would be interesting to offer a pre-test before the start of the academic year, teach the target DMs for two hours a week over two or three semesters and then follow with post- and delayed tests. Diaries could be kept on a weekly basis throughout the course of the teaching and focus groups could be carried out after the teaching is completed. This type of study may well produce different results and fits with the kind of longitudinal design which Schmitt (2010: 156) recommends for lexical studies: "In summary, vocabulary learning is longitudinal and incremental in nature and only research designs with a longitudinal element can truly describe it". Research could also be carried out in other contexts, such as with EFL learners, with researchers adapting the language focus to those areas which may be of most use in a particular teaching situation in order to find out the most effective way of teaching DMs or other aspects of spoken grammar.

\section{REFERENCES}

Aijmer, K. (2002). English Discourse Particles. Amsterdam: John Benjamins.

Anderson, J. (1982). Acquisition of cognitive skill. Psychological Review, 89(4), 369-406.

Biber, D., Johansson, S., Leech, G., Conrad, S., \& Finegan, E. (1999). Longman Grammar of Spoken and Written English. London: Longman.

Byrne, D. (1986). Teaching Oral English. Harlow: Longman.

Carter, R., \& McCarthy, M. (1997). Exploring Spoken English. Cambridge: Cambridge University Press.

Carter, R., \& McCarthy, M. (2006). Cambridge Grammar of English. Cambridge: Cambridge University Press.

Channell, J. (1994). Vague Language. Oxford: Oxford University Press.

Chaudron, C., \& Richards, J. C. (1986). The effect of discourse markers on the comprehension of lectures. Applied Linguistics, 7(2), 113-127.

Cohen, L., Manion, L., \& Morrison, K. (2007). Research Methods in Education. New York: Routledge.

Compleat Lexical Tutor (2012). Retrieved January 5, 2012, from http://www.lextutor.ca/

Council of Europe (2001). Common European Framework of Reference for Language: Learning, Teaching, Assessment. Cambridge: Cambridge University Press. 
Cullen, R., \& Kuo, I. C. (2007). Spoken grammar and ELT course materials: A missing link? TESOL Quarterly, 41(2), 361-386.

Cutting, J. (Ed.) (2000). The Grammar of Spoken English and EAP Teaching. Sunderland: Sunderland University Press.

DeKeyser, R. M. (Ed.) (2007a). Practice in a Second Language. Perspectives from Applied Linguistics and Cognitive Psychology. Cambridge: Cambridge University Press.

DeKeyser, R. M. (2007b). Conclusion: The future of practice. In R. M. DeKeyser (Ed.), Practice in a Second Language. Perspectives from Applied Linguistics and Cognitive Psychology (pp. 287304). Cambridge: Cambridge University Press.

DeKeyser, R. M. (2007c). Study abroad as foreign language practice. In R. M. DeKeyser (Ed.), Practice in a Second Language. Perspectives from Applied Linguistics and Cognitive Psychology (pp. 208-226). Cambridge: Cambridge University Press,.

Dornyei, Z. (2007). Research Methods in Applied Linguistics. Oxford: Oxford University Press.

Ellis, R. (2002). Grammar teaching - practice or consciousness-raising? In J. C. Richards, \& W. A. Renandya (Eds.), Methodology in language teaching: An anthology of current practice (pp. 167-174). Cambridge: Cambridge University Press.

Eslami, Z. R., \& Eslami-Rasekh, A. (2007). Discourse markers in academic lectures. Asian ELT Journal, 9(1), 22-38.

Fraser, B. (1996). Pragmatic markers. Journal of Pragmatics, 6(2), 167-190.

Fraser, B. (1999). What are discourse markers? Journal of Pragmatics, 31(7), 931-952.

Fung, L., \& Carter, R. (2007). Discourse markers and spoken English: Native and non-native use in pedagogic settings. Applied Linguistics, 28(3), 410-439.

Hellermann, J., \& Vergun, A. (2007). Language which is not taught: The discourse marker use of beginning adults learners of English. Journal of Pragmatics, 39(1), 157-179.

Henandez, T. (2008). The effect of explicit instruction and input flood on students' use of Spanish discourse markers on a simulated oral proficiency interview. Hispania, 19(3), 665-675.

Hernandez, T. (2011). The Role of Explicit Instruction and Input Flood on the Acquisition of Spanish Discourse Markers. Language Teaching Research, 15(2), 159-182.

Jones, C. (2010). Spoken discourse markers: What are they and why teach them? In Recent Approaches to Teaching and Assessing Speaking: Selected Articles by the Presenters of the IATEFL Testing, Evaluation and Assessment Special Interest Group Conference in Famagusta, Cyprus 23-24 October 2009 (pp. 84-89). IATEFL (TEA SIG).

Jucker, A., \& Ziv, Y. (Eds.). (1998). Discourse Markers: Descriptions and Theory. Amsterdam: John Benjamins.

Kelle, U. (2002). Computer-assisted qualitative data analysis. In C. Seale, G. Gobo, J. F. Gubrium, \& D. Silverman (Eds.), Qualitative Research Practice (pp. 473-489). London: SAGE.

Krishnan, L. A., \& Hoon, L. H. (2002). Diaries: Listening to 'voices' from the multicultural classroom. ELT Journal, 56(3), 227-239.

Leech, G. (2000). Grammars of spoken English: New outcomes of corpus-oriented research. Language Learning, 50(4), 675-724.

Lewis, M. (1993). The Lexical Approach. Hove: Language Teaching Publications.

Lindsay, C., \& Knight, P. (2006). Learning and Teaching English. A Course for Teachers. Oxford: Oxford University Press.

McCarthy, M., \& Carter, R. (1995). Spoken grammar: What is it and how can we teach it? ELT Journal, 49(3), 207-218.

Morgan, D. L. (1997). Focus Groups as Qualitative Research. London: SAGE.

Muller, S. (2004). 'Well you know that type of person': Functions of 'well' in the speech of American and German students. Journal of Pragmatics, 36(6), 1157-1182.

Norris, J. M., \& Ortega, L. (2000). Effectiveness of L2 instruction: A research synthesis and quantitative meta-analysis. Language Learning, 50(3), 417-528.

Norris, J. M., \& Ortega, L. (2001). Does type of instruction make a difference? Substantive findings fom a meta-analytic review. In R. Ellis (Ed.), Form-Focused Instruction and Second Language Learning (pp. 157-213). Oxford: Blackwell.

O'Keeffe, A., McCarthy, M., \& Carter, R. (2007). From Corpus to Classroom. Cambridge: Cambridge University Press. 
Ortega, L. (2007). Meaningful L2 practice in foreign language classrooms: A cognitive-interactionist SLA perspective. In R. M. Dekeyser (Ed.), Practice in a Second language. Perspectives from Applied Linguistics and Cognitive Psychology (pp. 180-207). Cambridge: Cambridge University Press.

Prodromou, L. (2003). In search of the successful user of English. Modern English Teacher, 12(2), 514.

Prodromou, L. (2008). English as a Lingua Franca: A Corpus-based Analysis. London: Continuum. QSR International (2012). Retrieved March 22, 2012, from http://www.qsrinternational.com

Redeker, G. (1991). Linguistic markers of discourse structure. Linguistics, 29(6), 1139-1172.

Schiffrin, D. (1987). Discourse Markers. Cambridge: Cambridge University Press.

Schmidt, R. W. (1990). The role of consciousness in second language learning. Applied Linguistics, $11(2), 129-158$.

Schmitt, N. (2010). Researching Vocabulary: A Vocabulary Research Manual. London: Palgrave.

Skehan, P. (1996). A Framework for the Implementation of Task-Based Instruction. Applied Linguistics, 17(1), 38-62.

Timmis, I. (2005). Towards a framework for teaching spoken grammar. ELT Journal, 59(2), 117-125.

Timmis, I. (2012). Spoken language research and ELT: Where are we now? ELT Journal, 66(4), 514522.

VanPatten, B. \& Cadierno, T. (1993). Input processing and second language acquisition. The Modern Language Journal, 77(1), 45-57.

Yoshimi, D. R. (2001). Explicit instruction and JFL learners' use of interactional discourse markers. In K. R. Rose \& G. Kasper (Eds.), Pragmatics in Language Teaching (pp. 223 244). Cambridge: Cambridge University Press.

\section{APPENDIX: TARGET DISCOURSE MARKERS AND THEIR FUNCTIONS}

\begin{tabular}{|c|c|c|}
\hline Function & Discourse markers & Examples \\
\hline $\begin{array}{l}\text { Opening } \\
\text { conversations/topics }\end{array}$ & Right, So & $\begin{array}{l}\text { Right, shall we start? } \\
\text { So, what do you think about the cuts? }\end{array}$ \\
\hline $\begin{array}{l}\text { Closing conversations and } \\
\text { topic boundaries }\end{array}$ & Right, Anyway & $\begin{array}{l}\text { Right, I think that's everything } \\
\text { Anyway, I'd better go, I'll see you next week. }\end{array}$ \\
\hline $\begin{array}{l}\text { Monitoring shared } \\
\text { knowledge }\end{array}$ & You see, You know & $\begin{array}{l}\text { You see, since I've hurt my back I can't walk very } \\
\text { well. } \\
\text { The weather in England is, you know, pretty awful. . }\end{array}$ \\
\hline Response tokens & Right & $\begin{array}{l}\text { A. I think we should go there first. } \\
\text { B. Right. }\end{array}$ \\
\hline Reformulating & I mean, Mind you & $\begin{array}{l}\text { I don't like English food. I mean, some of it is ok but } \\
\text { most of it I don't like. } \\
\text { The weather in England is terrible. Mind you, I guess } \\
\text { it's OK sometimes. }\end{array}$ \\
\hline Pausing & Well & $\begin{array}{l}\text { A. What do you think of the plan? } \\
\text { B. Well, let's see. I guess it's a good idea. }\end{array}$ \\
\hline Sequencing & In the end, First, Then, & $\begin{array}{l}\text { First, we started walking quickly... } \\
\text { Then, we started running... } \\
\text { In the end, we managed to escape. }\end{array}$ \\
\hline Shifting & Well & $\begin{array}{l}\text { A. Do you live in Preston? } \\
\text { B. Well, near Preston. }\end{array}$ \\
\hline Resuming & $\begin{array}{l}\text { Anyway, As I was saying, } \\
\text { Where was I? }\end{array}$ & $\begin{array}{l}\text { Erm, yeah, anyway, we started walking really fast } \\
\text { Erm, yeah as I was saying, we started walking really } \\
\text { fast } \\
\text { Erm, where was I? We started walking fast and then } \\
\text { started running. }\end{array}$ \\
\hline Introducing examples & Like & $\begin{array}{l}\text { I think being healthy is much more important so you } \\
\text { need to have, like, green food. }\end{array}$ \\
\hline Justifying & ${ }^{\circ} \mathrm{Cos}$ & I don't want to go cos it's too expensive. \\
\hline
\end{tabular}

(C) Servicio de Publicaciones. Universidad de Murcia. All rights reserved. IJES, vol. 14 (1), 2014, pp. 37-54 Print ISSN: 1578-7044; Online ISSN: 1989-6131 